Fifth International Conference on Sustainable Construction Materials and Technologies. http://www.claisse.info/Proceedings.htm

\title{
EFFECT OF RICE HUSK ASH AND MARBLE POWDER ON MECHANICAL BEHAVIOR OF CONCRETE
}

\author{
Dr. Maria Idrees ${ }^{1}$, Shimza Jamil ${ }^{2}$ \\ ${ }^{1}$ Assistant Professor, Department of Architectural Engineering \& Design, University of \\ Engineering \& Technology Lahore, Pakistan. mariaidrees@uet.edu.pk \\ ${ }^{2}$ Department of Architectural Engineering \& Design, University of Engineering \& Technology \\ Lahore, Pakistan. engr.sh.jamil@gmail.com
}

\begin{abstract}
The research focuses on the mechanical behavior of concrete with the waste rice husk ash (RHA) and marble powder (MP) as partial cement and sand replacement materials respectively. The waste rice husk ash is sieved and burnt at $750^{\circ} \mathrm{C}$ for 6 hours. The separate and combined effects of RHA $(10 \& 15 \%)$ and MP $(10 \& 20 \%)$ are investigated. Compressive, split cylinder tensile and flexural strengths of these concrete at 7, 28 and 56 days showed comparable results to those of ordinary concrete. The sieved (but not ground) RHA caused a slight reduction in the concrete strength while MP enhanced the strengths. The combined MP and RHA either increased the strengths or showed similar results in an acceptable range. The utilization of RHA and MP in concrete effectively transform these waste materials into useful products thus resolving the disposal and natural resource exhaustion issues, providing an environmentally friendly, economical and sustainable concretes.
\end{abstract}

Keywords: Rice husk ash, Marble powder, cement replacement material, sand replacement material, strengths, sustainable material.

\section{INTRODUCTION}

Recycling of waste material in the construction industry has gained a lot of attention nowadays. It resolves many issues regarding environmental sustainability, disposal of waste materials and the exhaustion of natural resources. Recycling of wastes as usable construction material leads to economical as well as environment-friendly construction. Pakistan is the fourth largest rice producer in the world (Prices, 2018). Its husk is produced in bulk and farmers usually burn husk as the most economical solution for the disposal. The rice husk ash produced as waste material is hazardous for the environment and needs to be dumped properly (El Damatty and Hussain, 2009). Agricultural countries should be aware of the rice husk ash utilization. The awareness that this waste can be a useful product, could lead toward its proper disposal/burning to achieve high quality, usable ash. 
Cement is a widely used and abundantly produced construction material. Production of the high amount of carbon dioxide ( 8 to $10 \%$ of global carbon dioxide production) has led to the depletion of ozone layer, greenhouse effect, and global warming that are alarming issues for the environmental sustainability (Suhendro, 2014). Currently, a lot of research is being carried out to resolve these issues by partial replacement of cement with different supplementary cementitious materials.

Rice husk ash (RHA) is one of the promising supplementary cementitious materials. Zerbino, Giaccio, and Marfil (2014) and Ferraro and Nanni (2012) have concluded RHA as an economical and environment-friendly partial cement substitute. It shows a good pozzolanic character if it has a high surface area (Givi et al., 2010) and high amorphous silica (Van Tuan et al., 2011). RHA characteristics are extremely sensitive to their fineness.

Nehdi, Duquette and El Damatty (2003) found that RHA below $45 \mu \mathrm{m}$ can participate in the pozzolanic activity. Very fine amorphous silica combines with calcium hydroxide $(\mathrm{CH})$ of hydrated cement paste to form calcium-silicate-hydrate $(\mathrm{CSH})$. Hence, the strength and durability of concrete are increased. Habeeb and Mahmud (2010) found that increasing the fineness of RHA enhanced strength results.

Initially, rice husk has 50\% cellulose, 25 to $30 \%$ lignin and 15 to $20 \%$ silica. On burning, crystalline or amorphous silica is produced in RHA. The color and chemical composition of RHA change with its burning temperature. The active silica plays a key role in pozzolanic potential and strength development (at a later age) (Antiohos, Papadakis and Tsimas, 2014). Bie et al (2015) found $600^{\circ} \mathrm{C}$ as appropriate furnace temperature. Fapohunda, Akinbile, and Shittu (2017) concluded in many research articles that RHA at $10 \%$ cement replacement provided the optimum results. Ordinarily, all RHA do not possess similar qualities due to different chemical composition, amorphous or crystalline phase, carbon content, and fineness but it does not mean that ordinary RHA cannot be used.

Chao-Lung, Anh-Tuan, and Chun-Tsun (2011) revealed that RHA can be used up to 20\% as a cement replacement for comparable strengths. (Abdul Rahim et al (2014) used different RHA percentages $5 \%, 15 \%$, and $25 \%$ as cement substituting material up to 28 days and found that lower percentages of RHA showed the better strengths.

Obilade (2014) replaced cement by 5, 10, 15, 20 and 25\% RHA by weight and performed compacting factor test in his research. The compacting factors decreased, as the percentage replacement of cement with RHA increased. Fapohunda, Akinbile, and Shittu (2017) state that RHA produced under controlled incineration is suitable for construction purpose and RHA up to $10 \%$ of cement replacement shows better results. RHA in concrete results in impervious concrete hence chloride ingress and sulfate attacks are controlled. RHA containing concrete shows better dimensional stability too.

Marble is a commonly used material all over the world. During the processing of marble from raw to polished form, 30-70\% of marble is wasted as marble powder. Marble powder is produced in huge amount as the waste material all over the world (Ulubeyli and Artir, 2015 and Hebhoub et al., 2011). Marble powder is alkaline in nature and produces 
environmental hazards. This large amount of wasted material needs to be disposed of properly.

Pakistan is the sixth largest country with marble reserves, having estimated 160 Million tons of marble reserves. Marble powder is being produced in large quantities during quarrying, cutting, polishing and shaping process of the marble. In contrast to the developed countries, Pakistan is using primitive mining techniques and locally fabricated machinery for this purpose. As a result, material wastage ratio in Pakistan is relatively high, which reaches up to $73 \%$ against the standard quarry wastage in the world i.e. 50\% of the gross production ('All Pakistan Marble Industry Association', 2018). This quarry wastage can be converted to powder form for use in concrete.

Sand is one of the most important construction materials which have been used extensively in mortars and concretes all over the world. The continuous extracting of sand from natural resources is causing depletion of good quality of sand and environmental issues. The natural resource of good quality sand should be used sustainably. Replacing of sand partially, by wasted marble powder is the solution to the aforementioned environmental problems. Marble powder can be used as sand replacement material if it does not cause any strength reduction or durability issues. The strength and durability of concrete depend on the chemical composition and fineness of marble powder used. The coarser marble powder leads to a different result than a finer one. Thus, extensive research has been conducted to find out the optimum percentages for achieving the best results.

Corinaldesi, Moriconi, and Naik (2010) carried out a study about the effect of marble powder; replacement of sand with $10 \%$ of marble powder provided the maximum compressive strength.

Alyamaç and Aydin (2015) studied 10, 20, 30, 40, 50 and $90 \%$ by volume of marble powder as sand replacement material and looked at 7,28 and 90 days compressive strength values. Marble powder was found suitable as sand replacement material up to $40 \%$. In order to understand the effects of marble powder on the mechanical properties and durability of concrete, Talah, Kharchi, and Chaid (2015) researched that marble powder made the concrete more resistant to chloride ions and oxygen penetration, hence the marble powder-incorporated concrete has better durability than ordinary concrete.

Singh et al (2017) used the UMBERTO NXT life cycle analysis software for the comparison of environmental impact on concrete with and without marble powder. The cost analysis was performed to establish the feasibility of marble powder as partial replacement material. The use of marble powder exhibited encouraging results in strength and quality.

Munir, Kazmi, and Wu (2017) found that the marble powder was efficient in controlling alkali-silica reactivity when it was used as cement replacement material in concrete production.

Marble powder contains $\mathrm{CaO}$ (from $\mathrm{CaCO}_{3}$ ), which is a binding material. Ashish et al (2016) used marble powder as partial cement replacement material up to $15 \%$ in a research study, and found good results and stated MP as a proper solution to the environmental hazards. 
Vardhan et al (2015) investigated the strength and durability properties of concrete in which marble powder was used as cement replacement material. The results revealed that the concrete with $10 \%$ marble powder replacement showed better performance in terms of strengths and durability.

Recent literature reviews, as discussed above, show that rice husk ash at lower percentages is best suited as cement replacement material and give optimum strengths and durability at approximately $10 \%$ replacement of cement by weight. Similarly, Marble powder can be used as sand replacement material and provides better results up to $20 \%$ of sand replacement. Corinaldesi, Moriconi, and Naik (2010) confirmed that concrete with $10 \%$ replacement of sand by marble powder showed maximum compressive strengths. Marble powder may also be used as cement replacement material but it depends on its higher fineness and $\mathrm{CaO}$ content. Coarser marble powder is suitable only as sand replacement material.

As Pakistan is among the world's top ten producers of rice husk and waste marble powder, the combined effect of both RHA and MP should be studied on concrete properties for the effective waste management and utilization. The optimum percentages of RHA and MP, for which the strengths and durability of normal concrete are not compromised, should be determined.

The research was carried out to understand the combined effects of RHA and MP on the mechanical properties of concretes. Hence, control concrete, concrete with RHA as cement replacement material up to $15 \%$, concrete with MP as sand replacement material up to $20 \%$ and concrete with both RHA and MP up to $15 \%$ and $20 \%$ as cement and sand substitute respectively, were tested. The replacement percentages were decided because they showed optimum results in recently performed previous research works as mentioned earlier. The investigation was carried out to identify the optimum percentages of both materials in the concrete and to find the effective usage of these combinations without much compromise in the strengths. The addition of RHA and MP substitutes in concrete formed the concretes with comparable strengths to the strengths of control concrete.

\section{RESEARCH SIGNIFICANCE}

The main aim of the study is to effectively utilize agricultural and industrial waste in the production of concrete. Proper waste disposal into useful products i.e. by utilization of waste marble powder and rice husk ash, conservation of natural resources (river sand), sustainability of environment (avoiding river deepening by sand removal, reduced carbon dioxide emission, and waste material disposal) are some benefits of utilizing the results of this research. In this investigation, RHA is sieved and thermally treated and its effect on strength of concrete is determined. Hence the proportion of waste materials, MP and thermally treated RHA, to which the modified concrete shows comparable strengths to normal concrete are determined. 


\section{EXPERIMENTAL METHOD}

\subsection{Material}

CEM I 42,5 N-type ordinary Portland cement complying with EN 197-1:2011, which is also 43 Grade according to IS 269:2015 was used. Rice husk ash from a rice mill was collected, passed through $74 \mu \mathrm{m}$ sieve and burnt up to $750^{\circ} \mathrm{C}$ for 6 hours. Blackish rice husk ash was turned into white after removal of carbon as carbon dioxide during furnace burning process. Waste marble powder was collected and used without any treatment. (See Figure 1). Polycarboxylic ether based superplasticizer was used in all combinations.
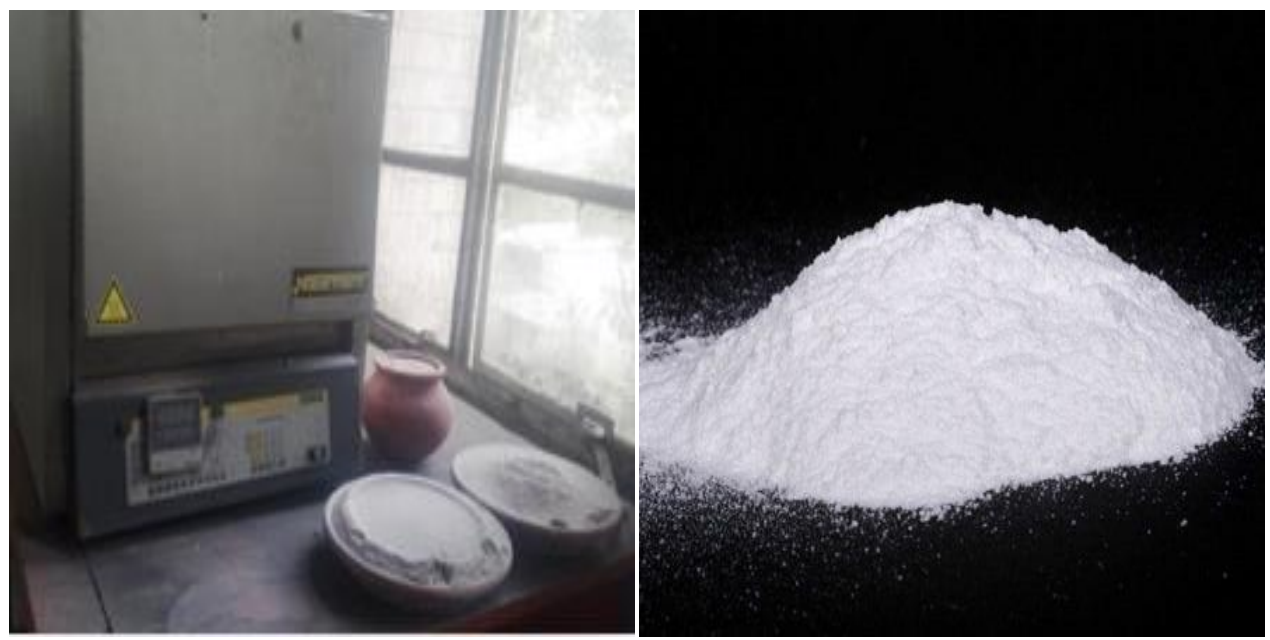

Figure 1: Treated Rice Husk Ash (Left) and Marble Powder (Right)

Physical properties of aggregates are shown in Table 1 and Figure 2. XRF analysis results for cement, RHA and MP are shown in Table 2 and sieve analyses of them are shown in Table 3.

Table 1 Physical properties of sand and crushed stone

\begin{tabular}{|c|c|c|}
\hline Physical properties & Sand & Crushed stone \\
\hline Water absorption $(\%)$ & 1.2 & 0.6 \\
\hline Specific gravity $\left(\mathrm{kg} / \mathrm{dm}^{3}\right)$ & 2.76 & 2.65 \\
\hline Compacted bulk density $\left(\mathrm{kg} / \mathrm{dm}^{3}\right)$ & 1.73 & 1.63 \\
\hline Loose bulk density $\left(\mathrm{kg} / \mathrm{dm}^{3}\right)$ & 1.59 & 1.42 \\
\hline Aggregate Impact value $(\%)$ & --- & 13.5 \\
\hline Fineness Modulus & 2.2 & 6.48 \\
\hline
\end{tabular}

Table no. 2: XRF analysis 


\begin{tabular}{|l|l|l|l|l|l|l|l|l|l|l|}
\hline Description & $\begin{array}{l}\mathrm{SiO}_{2} \\
\%\end{array}$ & $\begin{array}{l}\mathrm{Al}_{2} \mathrm{O} \\
3 \%\end{array}$ & $\begin{array}{l}\mathrm{Fe}_{2} \mathrm{O} \\
3 \%\end{array}$ & $\begin{array}{l}\mathrm{CaO} \\
\%\end{array}$ & $\begin{array}{l}\mathrm{Mg} \\
\mathrm{O} \%\end{array}$ & $\begin{array}{l}\mathrm{K}_{2} \\
\mathrm{O}\end{array}$ & $\begin{array}{l}\mathrm{Na}_{2} \\
\mathrm{O} \%\end{array}$ & $\begin{array}{l}\mathrm{SO}_{3} \\
\%\end{array}$ & $\begin{array}{l}\text { LOI } \\
\%\end{array}$ & $\begin{array}{l}\text { Blaine } \mathrm{cm}^{2} / \\
\mathrm{g}\end{array}$ \\
\hline Rice Husk Ash & $\begin{array}{l}84.6 \\
9\end{array}$ & 1.68 & 2.60 & 1.83 & 2.83 & $\begin{array}{l}1.7 \\
9\end{array}$ & 0.33 & $\begin{array}{l}1.9 \\
7\end{array}$ & 0.95 & - \\
\hline $\begin{array}{l}\text { Marble } \\
\text { Powder }\end{array}$ & 1.33 & 0.32 & 0.09 & 55.50 & 1.16 & $\begin{array}{l}0.1 \\
3\end{array}$ & 0.17 & $\begin{array}{l}0.0 \\
0\end{array}$ & $\begin{array}{l}41.0 \\
5\end{array}$ & - \\
\hline $\begin{array}{l}\text { Cement } \\
\text { Sample }\end{array}$ & $\begin{array}{l}20.2 \\
5\end{array}$ & 5.05 & 3.13 & 62.13 & 2.29 & $\begin{array}{l}0.7 \\
4\end{array}$ & 0.24 & $\begin{array}{l}2.5 \\
7\end{array}$ & 4.42 & 3090 \\
\hline
\end{tabular}

Table 3 Sieve analysis of finer particles

\begin{tabular}{|c|c|c|c|}
\hline \multirow{2}{*}{ Description } & \multicolumn{3}{|c|}{ Residue \% } \\
\cline { 2 - 4 } & $\begin{array}{c}32 \mu \mathrm{m} \\
(\text { Sieve No 450) }\end{array}$ & $\begin{array}{c}45 \mu \mathrm{m} \\
(\text { Sieve No 325) }\end{array}$ & $\begin{array}{c}90 \mu \mathrm{m} \\
\text { (Sieve No } \\
170)\end{array}$ \\
\hline Rice Husk Ash & - & 72.67 & - \\
\hline Marble Powder & 78.62 & 75.10 & 57.30 \\
\hline Cement & 29.59 & 17.50 & 1.72 \\
\hline
\end{tabular}

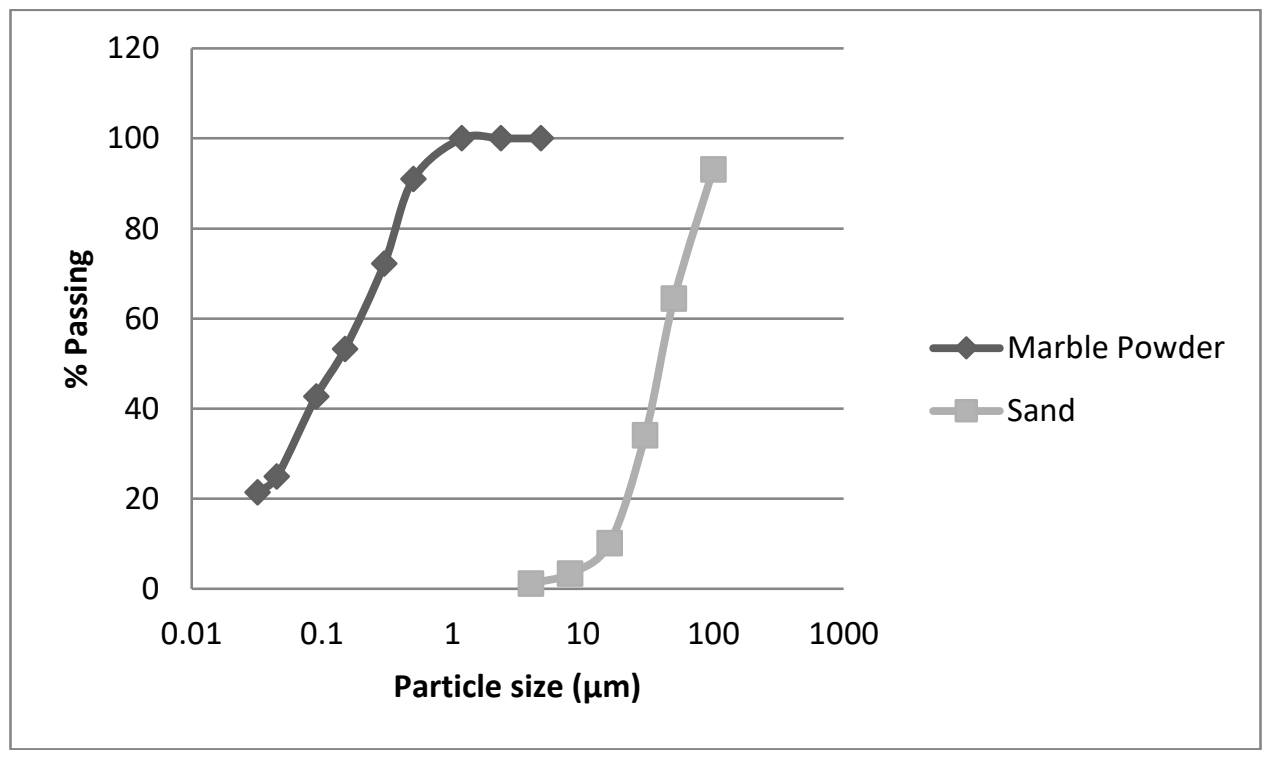

Figure 2 Particle size distribution of fine aggregates 


\subsection{Experimentation}

Concrete mixes were prepared for partial cement replacement by RHA only (10\% and $15 \%$ ), for partial sand replacement by MP only (10\% and 20\%) and all of their combinations as shown in Table 4. We selected these percentages because these percentages of RHA and MP provided optimum strengths to concrete in previously conducted studies cited above. For environmental sustainability, we need to use maximum waste materials without compromising strengths. The control mix was designed for normal concrete i.e. $20 \mathrm{MPa}$ with water binder ratio 0.58 and polycarboxylic ether based superplasticizer. The adsorption of water by RHA and MP (the replacement materials) increase the water requirement. The combinations enlisted in Table 4 were cast into cylinders and prisms and tested for compressive, splitting tensile and flexural strengths at 7, 28 and 56 days as shown in Figure 3.

Table 4 Mix designs of concrete productions

\begin{tabular}{|c|c|c|c|}
\hline No & Mixture codes & RHA (\%) & $\operatorname{MP}(\%)$ \\
\hline 1 & A0M0 (control) & \multirow{3}{*}{0} & 0 \\
\hline 2 & A0M10 & & 10 \\
\hline 3 & $\mathrm{~A} 0 \mathrm{M} 20$ & & 20 \\
\hline 4 & A10M0 & \multirow{3}{*}{10} & 0 \\
\hline 5 & A10M10 & & 10 \\
\hline 6 & A10M20 & & 20 \\
\hline 7 & A15M0 & \multirow{3}{*}{15} & 0 \\
\hline 8 & A15M10 & & 10 \\
\hline 9 & A15M20 & & 20 \\
\hline
\end{tabular}

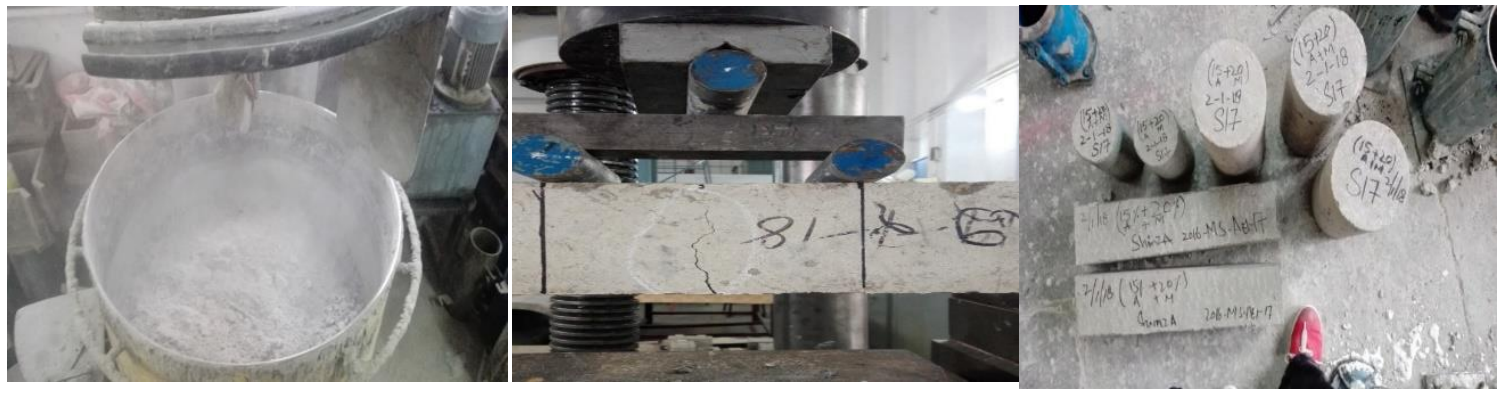

Figure 3 Experimentation

\section{RESULTS AND DISCUSSION}

\subsection{General:}

When finer material is used in concrete production, these particles entrap and adsorb water. Thus less water is available for hydration reactions. It results in a high water 
requirement for completing the reactions. Hence the strength is lowered if the higher amount of finer material (higher than optimum amount) along high water content is used. The water binder ratio was 0.58 and superplasticizer was used to improve the workability. The pozzolanic activity of rice husk ash depends on silica content, fineness and amorphous nature of ash. Therefore, depending on these three properties, the rice husk ash provided the strengths to concrete.

XRF results showed that rice husk ash used in this study had $84.69 \%$ silica content (Table 2). It was finer than 74 micrometers (passed through sieve number 200). The pozzolanic activity could be enhanced by grinding RHA, but it would make RHA expensive. The rice husk ash showed slightly lower strength results at 10 and $15 \%$ cement replacement.

The coarser marble powder is an inert material. We used MP as partial sand replacement material because various studies cited above showed that marble powder can also be used (up to 5 or $10 \%$ ) as partial cement replacement material.

MP showed high strength when used as partial sand replacement material in concrete combinations. Though we replaced sand by marble powder, the presence of high $\mathrm{CaO}$ content $(55 \%)$ in very fine particles of marble powder provided it better binding capacity. The higher strengths obtained at $10 \%$ and $20 \%$ replacement is due to the extra binding capacity of very fine marble powder present in the concrete. Though marble powder was used as partial sand replacement material, it also provided cementitious characteristics and higher strengths to concrete. In fact, the ratio of water to cementitious material was decreased (initially 0.58 ) due to the cementitious property of very fine MP particles.

\subsection{Compressive Strength}

10\% MP showed a remarkable increase in compressive strength. 20\% MP used specimens had lower strength than 10\% MP used specimens but their strengths were higher than the control mix. This decrease can be explained with the higher water requirement of $20 \%$ MP added specimens due to finer particles.

MP concrete showed higher strength. Table 3 shows almost three-quarters of particles were smaller than $45 \mu \mathrm{m}$ and $21.38 \%$ particles were smaller than $32 \mu \mathrm{m}$. Fine particles with $55 \% \mathrm{CaO}$ content raised the strength by increasing cementitious characteristics. The results (Figure 4) reveal that compressive strength decreased slightly with an increase in RHA amount. Only $27.33 \%$ of RHA particles are smaller than $45 \mu \mathrm{m}$ (Table 4) and hence will participate in the pozzolanic activity. Pozzolanic activity is the production of $\mathrm{CSH}$ by reaction of amorphous fine silica with $\mathrm{CH}$ (formed during the hydration process of cement particles). 


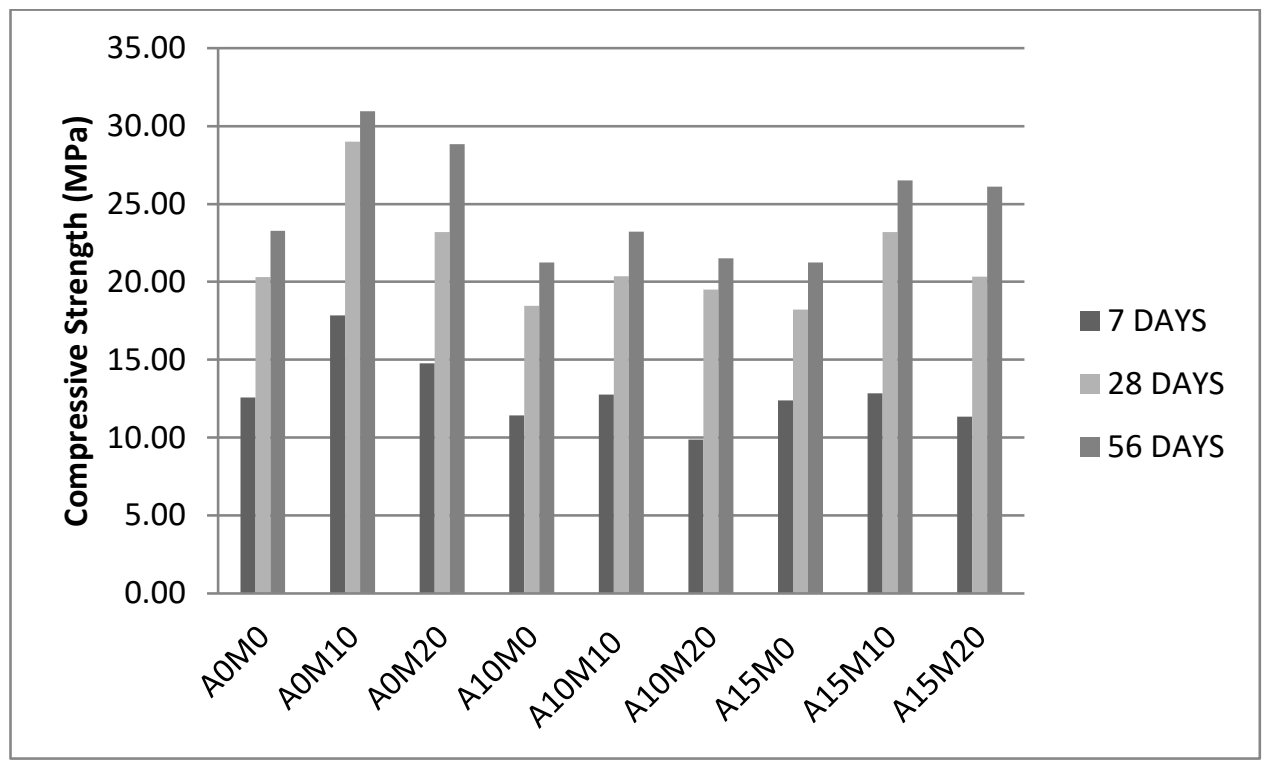

Figure 4 Compressive strengths

The combined use of MP\&RHA showed comparable results to the control mix. The strength gain of concrete with marble powder and rice husk ash depends on its chemical composition ( $\mathrm{CaO}$ and amorphous $\mathrm{SiO}_{2}$, high surface area). The strengths vary depending on the individual properties of the constituents.

The comparable compressive strength resulted due to lime from finer MP and silica from finer RHA, along with cement hydration products, producing $\mathrm{CSH}$, which contributed to higher strengths.

\subsection{Tensile strength}

Figure 5 shows that splitting tensile strengths were increased with the replacement of cement with MP, especially for 10\% replacement. $20 \%$ replacement showed higher strength than control but lower strength than $10 \%$ due to high water requirement. RHA was not fine enough to be used as cement replacing material and showed lower splitting tensile strengths. However, all combinations showed comparable results to conventional concrete. Hence RHA and MP can be used together to form environmental friendly and economical concrete. 


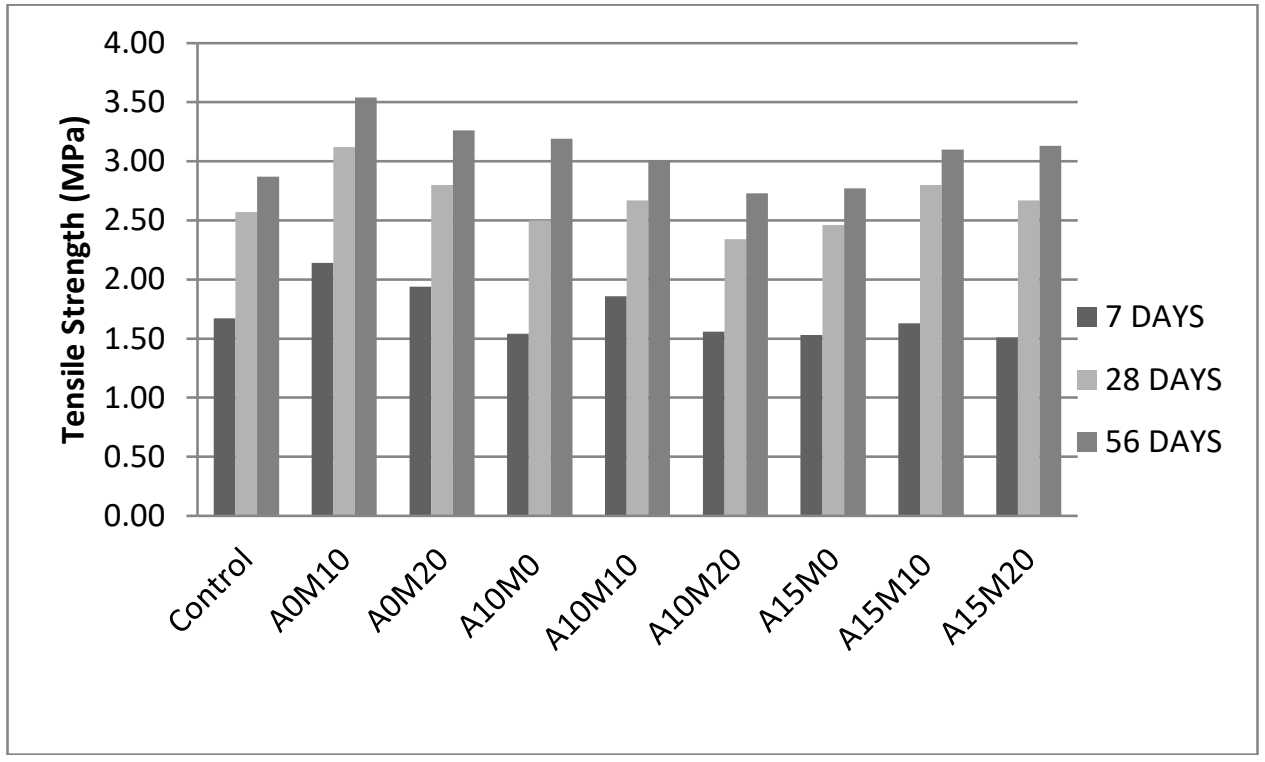

Figure 5 Splitting tensile strengths

\subsection{Flexural Strength}

Four point flexural strength results of prism showed that RHA and MP combinations provided comparable results to ordinary concrete indicating its safe use in beams (Figure 6). RHA and MP concrete is economical, environment-friendly and sustainable.

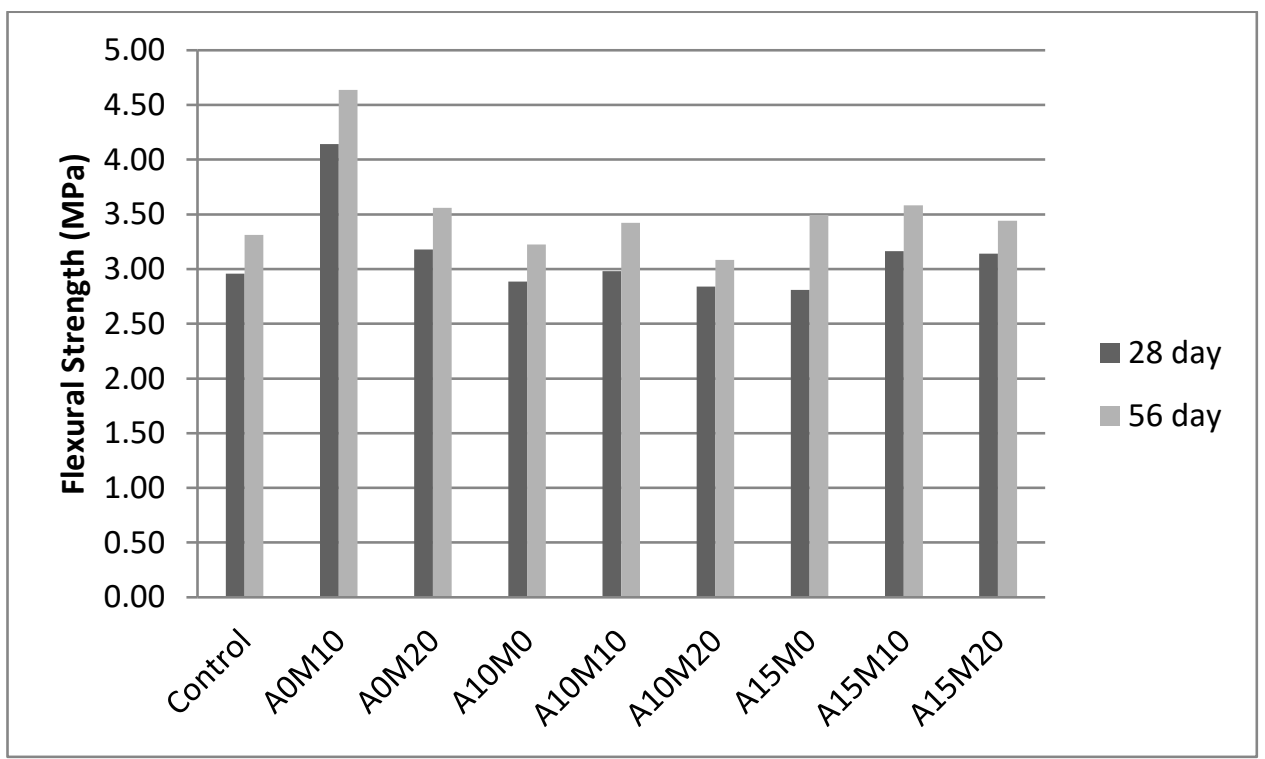

Figure no. 6: Flexural strengths 


\section{CONCLUSIONS}

The aim of this investigation was to explore the utilization of rice husk ash and marble powder as cement and sand replacement material respectively. The combined effect of RHA and MP was investigated on compressive, tensile and flexural strengths of concrete. Following conclusions were drawn.

The thermally treated rice husk ash with $84.69 \%$ silica content, passing through $74 \mu \mathrm{m}$ sieves, did not increase the strength at $10 \%$ and $15 \%$ replacement of cement.

Marble powder (at 10 and 20\% replacement of sand by weight) increased the strength of concrete, both separately and in combinations with rice husk ash. Usage of 10\% MP showed higher strengths than 20\% MP.

The concrete made up of rice husk ash and marble powder both showed acceptable strength results. RHA and MP are useful if used as cement and sand replacement materials respectively for producing normal strength concrete.

Following trends for compressive, splitting tensile and flexural strengths were obtained in this investigation.

$\mathrm{MP}$ concrete $>\mathrm{OPC}$ concrete $\simeq \mathrm{RHA}+\mathrm{MP}$ concrete $>$ RHA concrete

The RHA+MP concrete is economical (reduce cement cost), environmentally friendly (less $\mathrm{CO}_{2}$ emission, dumping of wastes in a usable manner, not extracting of sand) and comparable to ordinary concrete in terms of compressive, tensile and flexural strengths.

The effectiveness of very fine MP up to the optimum amount to increase the strengths may be linked to its $\mathrm{CaO}$ content and higher surface area.

In the investigation, RHA was passed through $74 \mu \mathrm{m}$ sieve only and then burnt, instead of grinding it mechanically. This simple approach was found not much effective for better performance of RHA as a cement substitute.

\section{ACKNOWLEDGMENT}

The authors wish to thank the University of Engineering and Technology, Lahore for providing graduate student research grant and facility. Thanks to PCL Lab for performing XRF analysis.

Lastly, special thanks to Dr. Ozgur Ekincioglu for his comments on the paper.

\section{REFERENCES}

Abdul Rahim, M. et al. (2014) 'Properties of Concrete with Different Percentage of the Rice Husk Ash (RHA) as Partial Cement Replacement', Materials Science Forum, 803, pp. 288-293. doi: 10.4028/www.scientific.net/MSF.803.288.

'All Pakistan Marble Industry Association' (2019).

Alyamaç, K. E. and Aydin, A. B. (2015) 'Concrete properties containing fine aggregate marble powder', KSCE Journal of Civil Engineering, 19(7), pp. 2208 2216. doi: 10.1007/s12205-015-0327-y.

Antiohos, S. K., Papadakis, V. G. and Tsimas, S. (2014) 'Rice husk ash (RHA) 
effectiveness in cement and concrete as a function of reactive silica and fineness', Cement and Concrete Research, 61-62, pp. 20-27. doi: 10.1016/j.cemconres.2014.04.001.

Ashish, D. K. et al. (2016) 'Properties of concrete incorporating sand and cement with waste marble powder', Advances in concrete construction, 4(2), pp. 145-160. doi: 10.12989/acc.2016.4.2.145.

Bie, R. S. et al. (2015) 'Studies on effects of burning conditions and rice husk ash (RHA) blending amount on the mechanical behavior of cement', Cement and Concrete Composites, 55, pp. 162-168. doi: 10.1016/j.cemconcomp.2014.09.008.

Chao-Lung, H., Anh-Tuan, B. Le and Chun-Tsun, C. (2011) 'Effect of rice husk ash on the strength and durability characteristics of concrete', Construction and Building Materials, 25(9), pp. 3768-3772. doi: 10.1016/j.conbuildmat.2011.04.009.

Corinaldesi, V., Moriconi, G. and Naik, T. R. (2010) 'Characterization of marble powder for its use in mortar and concrete', Construction and Building Materials, 24(1), pp. 113-117. doi: 10.1016/j.conbuildmat.2009.08.013.

El Damatty, A. A. and Hussain, I. (2009) 'An economical solution for the environmental problem resulting from the disposal of rice straw', in Appropriate Technologies for Environmental Protection in the Developing World: Selected Papers from ERTEP 2007, July 17-19 2007, Ghana, Africa, pp. 15-23. doi: 10.1007/978-1-4020-9139-1_3.

Fapohunda, C., Akinbile, B. and Shittu, A. (2017) 'Structure and properties of mortar and concrete with rice husk ash as partial replacement of ordinary Portland cement - A review', International Journal of Sustainable Built Environment. doi: 10.1016/j.jisbe.2017.07.004.

Ferraro, R. M. and Nanni, A. (2012) 'Effect of off-white rice husk ash on strength, porosity, conductivity and corrosion resistance of white concrete', Construction and Building Materials, 31, pp. 220-225. doi: 10.1016/j.conbuildmat.2011.12.010.

Givi, A. N. et al. (2010) 'Assessment of the effects of rice husk ash particle size on strength, water permeability and workability of binary blended concrete', Construction and Building Materials, 24(11), pp. 2145-2150. doi: 10.1016/j.conbuildmat.2010.04.045.

Habeeb, G. A. and Mahmud, H. Bin (2010) 'Study on properties of rice husk ash and its use as cement replacement material', Materials Research. doi: 10.1590/S151614392010000200011.

Hebhoub, H. et al. (2011) 'Use of waste marble aggregates in concrete', Construction and Building Materials. Elsevier, 25(3), pp. 1167-1171. doi: 10.1016/J.CONBUILDMAT.2010.09.037.

Munir, M. J., Kazmi, S. M. S. and Wu, Y. F. (2017) 'Efficiency of waste marble powder in controlling alkali-silica reaction of concrete: A sustainable approach', Construction and Building Materials, 154, pp. 590-599. doi: 10.1016/j.conbuildmat.2017.08.002.

Obilade, I. . (2014) 'Use Of Rice Husk Ash As Partial Replacement For Cement In Concrete', International Journal of Engineering And Applied Science, pp. 11-16.

Prices, R. (2018) 'Overview for 2018/19', 4(June).

Singh, M. et al. (2017) 'A study on environmental and economic impacts of using waste 
marble powder in concrete', Journal of Building Engineering. doi: 10.1016/j.jobe.2017.07.009.

Suhendro, B. (2014) 'Toward green concrete for better sustainable environment', in Procedia Engineering, pp. 305-320. doi: 10.1016/j.proeng.2014.12.190.

Talah, A., Kharchi, F. and Chaid, R. (2015) 'Influence of Marble Powder on High Performance Concrete Behavior', in Procedia Engineering, pp. 685-690. doi: 10.1016/j.proeng.2015.08.010.

Van Tuan, N. et al. (2011) 'Hydration and microstructure of ultra high performance concrete incorporating rice husk ash', Cement and Concrete Research, 41(11), pp. 1104-1111. doi: 10.1016/j.cemconres.2011.06.009.

Ulubeyli, G. C. and Artir, R. (2015) 'Properties of Hardened Concrete Produced by Waste Marble Powder', Procedia - Social and Behavioral Sciences, 195, pp. 2181-2190. doi: 10.1016/j.sbspro.2015.06.294.

Vardhan, K. et al. (2015) 'Mechanical properties and microstructural analysis of cement mortar incorporating marble powder as partial replacement of cement', Construction and Building Materials, 96, pp. 615-621. doi: 10.1016/j.conbuildmat.2015.08.071.

Zerbino, R., Giaccio, G. and Marfil, S. (2014) 'Evaluation of alkali-silica reaction in concretes with natural rice husk ash using optical microscopy', Construction and Building Materials, 71, pp. 132-140. doi: 10.1016/j.conbuildmat.2014.08.022. 